\title{
1.5 Варіант улаштування прохідної підвісної стелі в межах міжфермового простору
}

В останні роки та у найближчій перспективі основними напрямками структурної реорганізації промислового будівництва $\epsilon$ розширення i реконструкція існуючих промислових об'єктів [66]. Також у зв'язку із сучасною тенденцією технічного переоснащення промислових підприємств виникає потреба реконструкції будинків і споруд, в яких вони розміщені.

Реконструкція - цей особливий вид будівельних робіт, який передбачає перебудову будівлі з метою часткової або повної зміни його функціонального призначення. Багато існуючих промислових об'єктів реконструюють під торговельно-офісні будівлі [67], в результаті чого постають питання розділення великих об'ємів приміщень додатковими проміжними перекриттями [68]. Також, 3 урахуванням того, що промислові будівлі в більшості $\epsilon$ великопрогоновими, 3 несучими кроквяними конструкціями, виникають проблеми з улаштуванням підвісних стель у верхніх поверхах. Самі підвісні стелі виконуються не прохідними або прохідними. В більшості випадків, для встановлення додаткових інженерних комунікацій та для їх обслуговування, застосовуються прохідні підвісні стелі. Такі підвісні стелі складаються з окремих несучих конструкцій та огороджуючих елементів. Несучі конструкції прохідних підвісних стель можуть закріплюватись до балок чи ферм (мал. 1) або до елементів каркасу будівлі (мал. 2). Огороджуючі елементи закріплюються чи опираються на несучі конструкції підвісних стель і можуть виконуватись з різних матеріалів. 


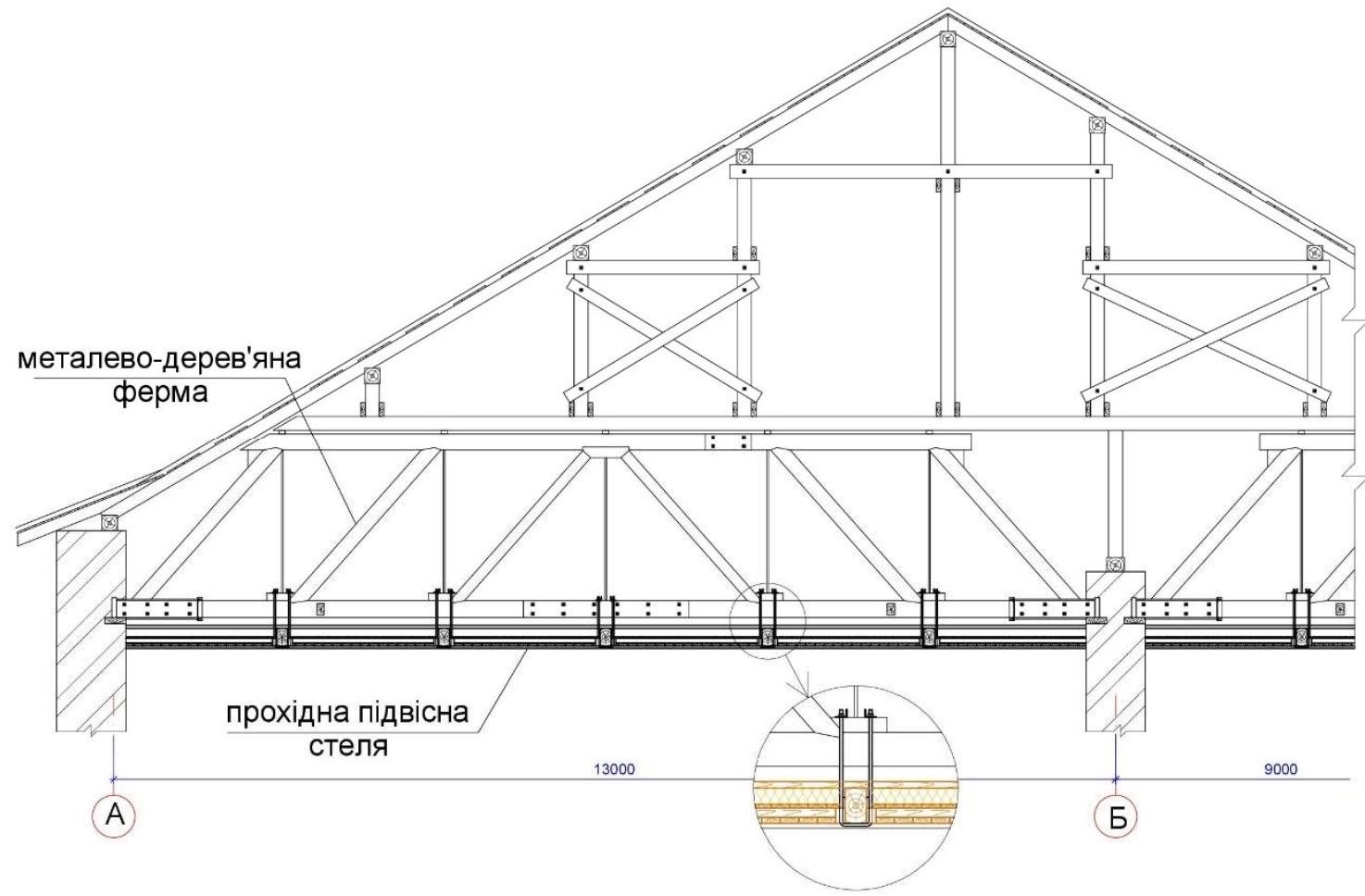

Малюнок 1. Підвіска прохідної підвісної стелі до нижнього поясу металодерев’яної ферми (несучі конструкції підвісної стелі - дерев’яні балки, огороджуючі елементи - дерев'яний щитовий настил)

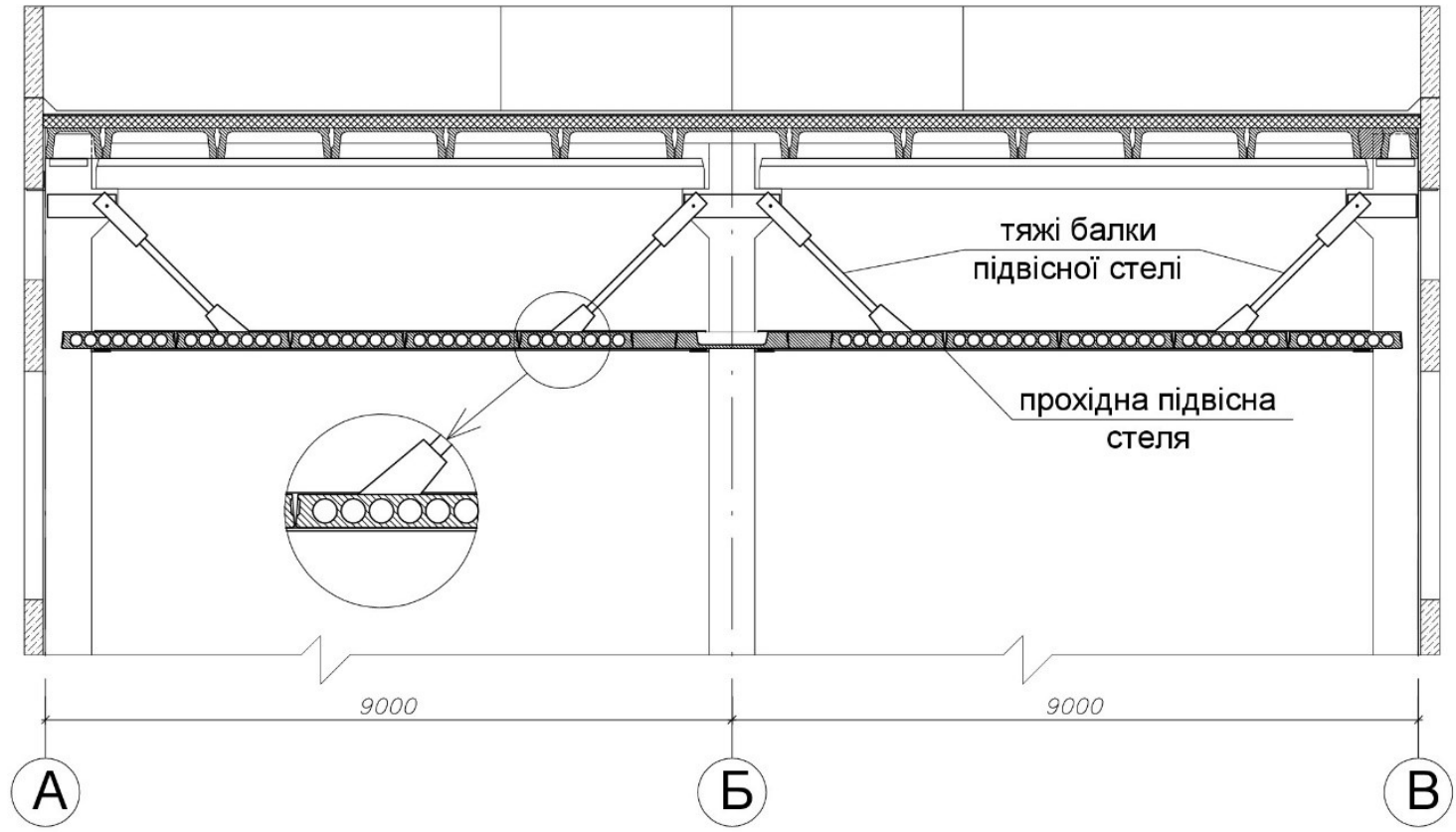

Малюнок 2. Підвіска прохідної підвісної стелі до колон каркасу (несучі конструкції підвісної стелі - металеві балки та тяжі, огороджуючі елементи залізобетонні плити)

В даному дослідженні розглядається однин з таких об’єктів у м. Львові, 
який на даний момент експлуатується як реконструйована торговельно-офісна громадська будівля. За конструктивним рішенням одноповерхова будівля складається із залізобетонних рам шириною 24,0 м, крок рам 12,0 м. В якості тримальних конструкцій покриття застосовані залізобетонні ферми 3 паралельними поясами. Висота від підлоги до низу ферм - 6,0 м, висота ферми 3,0 м. Реконструкція передбачала розділення внутрішнього об’єму (в межах ширини 9,0 м) на 2 поверхи (мал. 3). Висота приміщень першого поверху прийнята 3,5 м, другого поверху - 3,4 м. Інший об'єм будівлі (не розділений поверхами) використовується в якості складський приміщень.

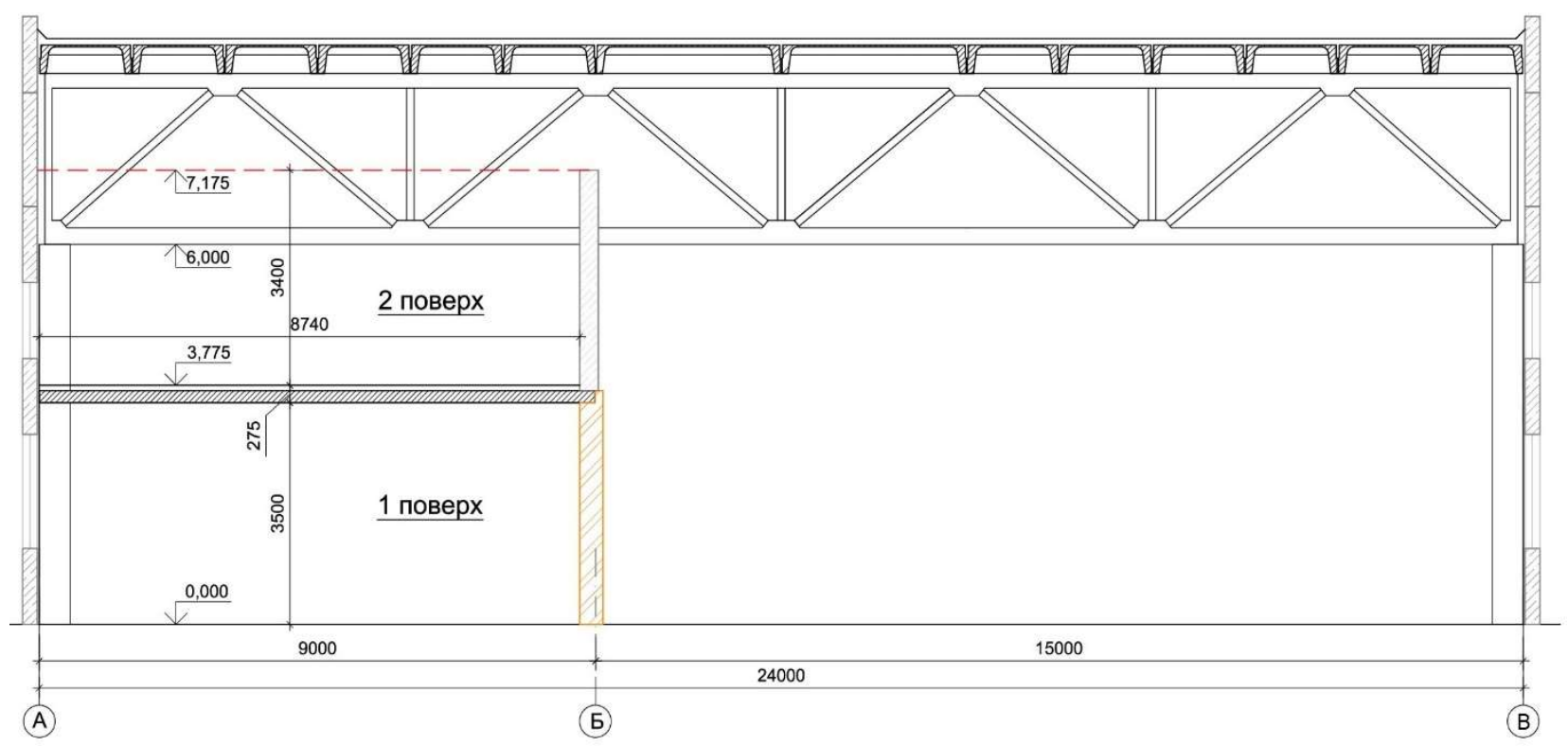

Малюнок 3. Поперечний переріз будівлі з вбудованими приміщеннями

3 урахуванням архітектурно-планувальних рішень, у приміщенні 2-го поверху $(8,74 \times 23,75$ м) не повинно бути проміжних опор, крім того, частина другого поверху потрапляє $\mathrm{y}$ міжфермовий простір i постає питання улаштування стелі даного поверху (мал. 3,4$)$. Також замовником поставлене завдання влаштування прохідної підвісної стелі, яка б сприймала навантаження від маси самої стелі, від розташованого на ній обладнання та зосереджене навантаження від ваги робітника з інструментом. 


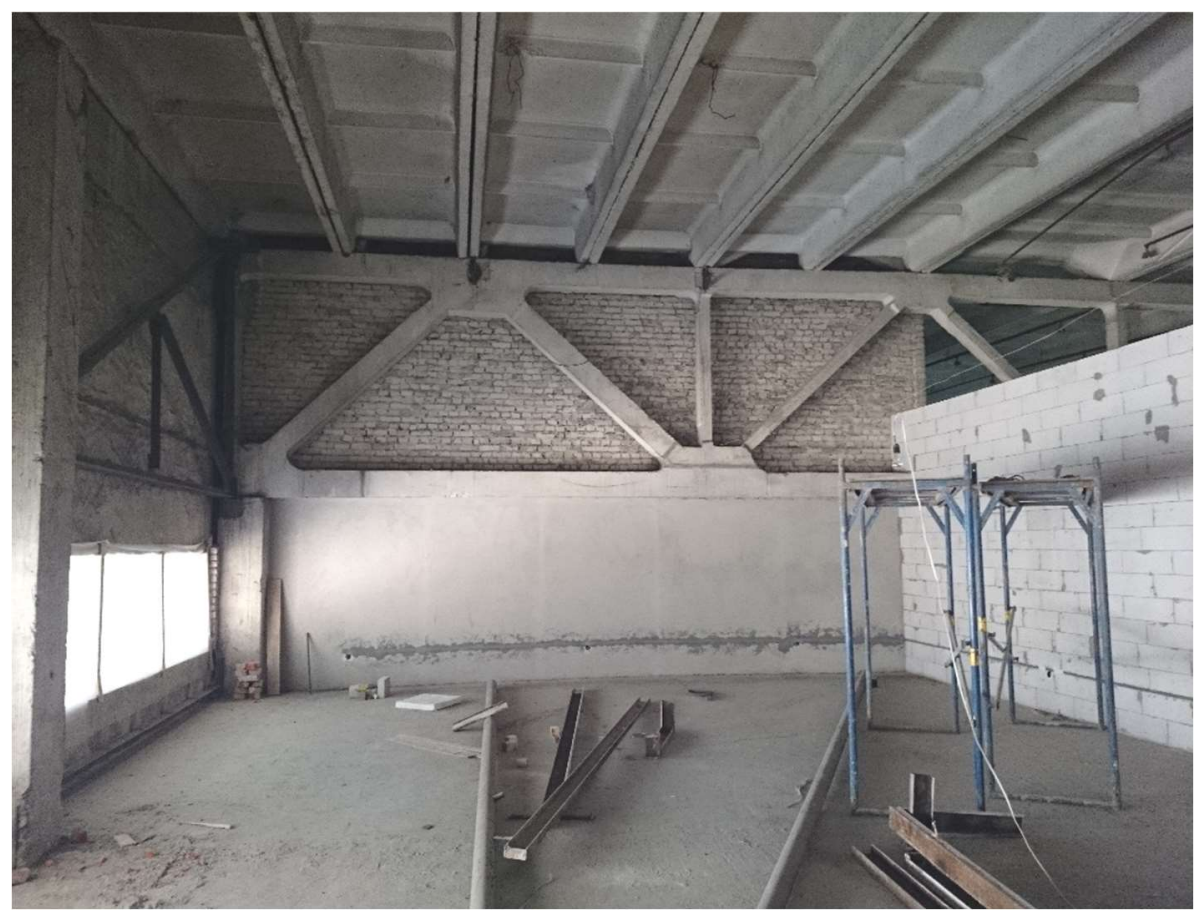

Малюнок 4. Другий поверх, що потрапляє у міжфермовий простір

Для досягнення поставленого завдання були запроектовані несучі конструкції підвісної стелі 3 окремих прогонів, які частково підвішені до існуючих залізобетонних ферм (мал. 5, 6, 7). Запроектовані прогони «Пр» довжиною 12,0 м з однієї сторони опираються на існуючі несучі цегляні стіни, а з другої сторони - підвішені до верхнього поясу ферми. Крок прогонів 3,0 м. Для зменшення проліту прогонів застосовані похилі тяжі «Т». Для забезпечення стійкості між прогонами влаштовані розпірки «Р». Всі прогони, тяжі та розпірки запроектовані зі сталевих прокатних профілів.

Для забезпечення відповідного температурного режиму в приміщеннях, підвісна стеля утепляється мінеральною ватою (між несучими прогонами). Зверху по прогонах влаштовуються прохідні містки для обслуговування. Архітектурою передбачено застосування в якості огороджуючих елементів стелі профільованого настилу. Застосований профільований настил НС44-1010-0.6 3 полімерним покриттям, який закріплюється до прогонів та частково опирається на нові стіни. Виступаючі у приміщення нижні частини ферм додатково обшиваються гіпсокартоном з подальшим оздобленням. 


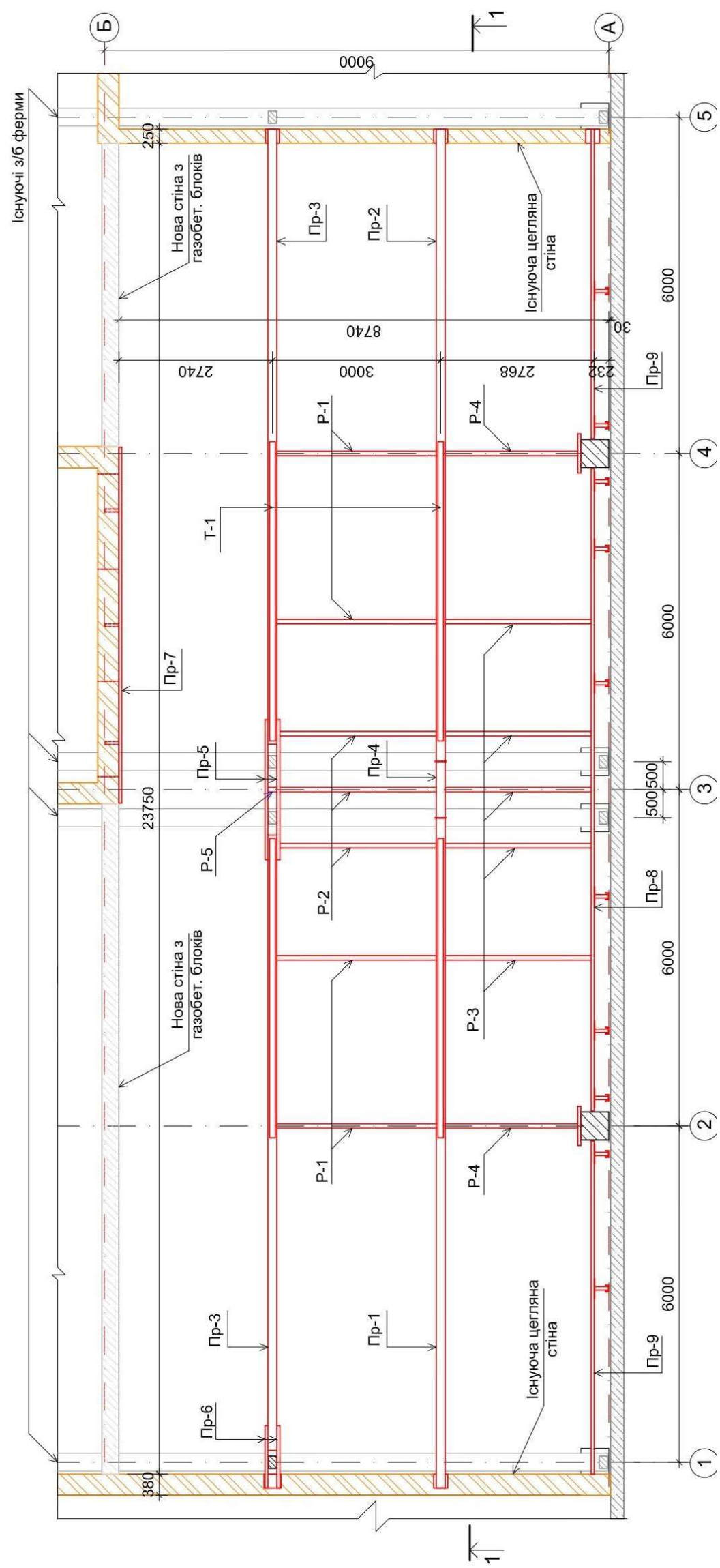

Малюнок 5. План розташування несучих конструкцій підвісної стелі 


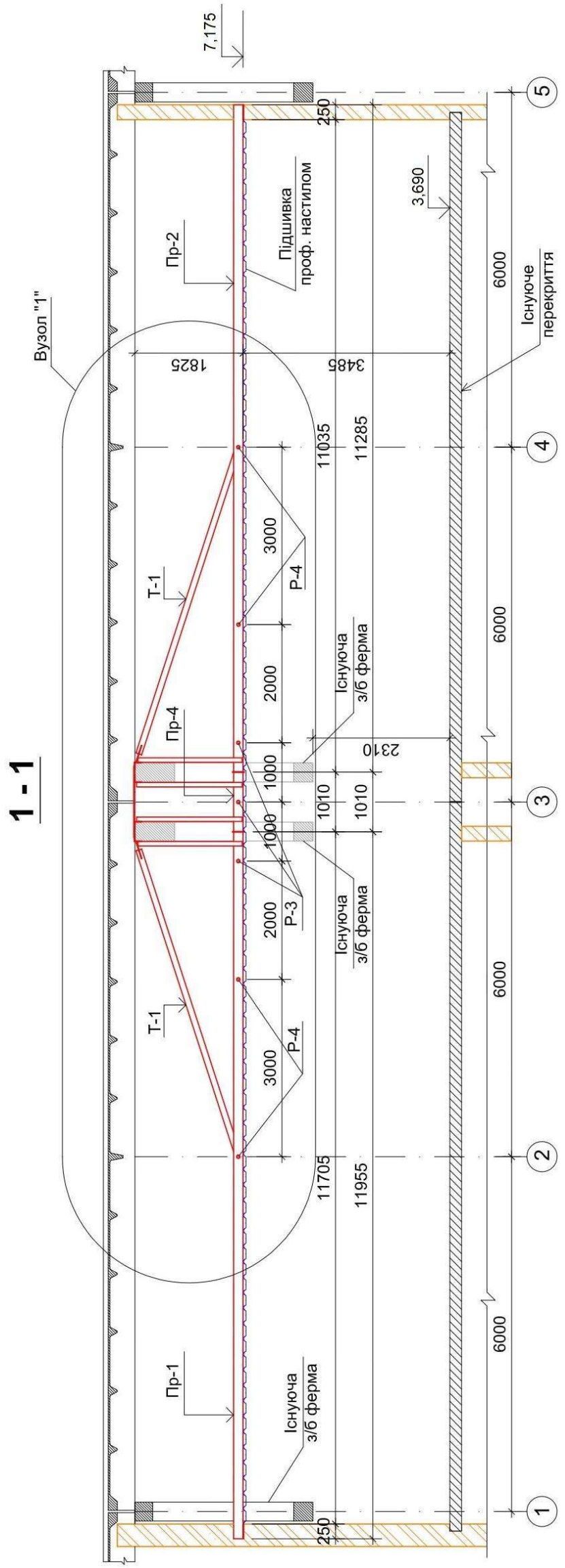

Малюнок 6. Поздовжній розріз «1-1» 


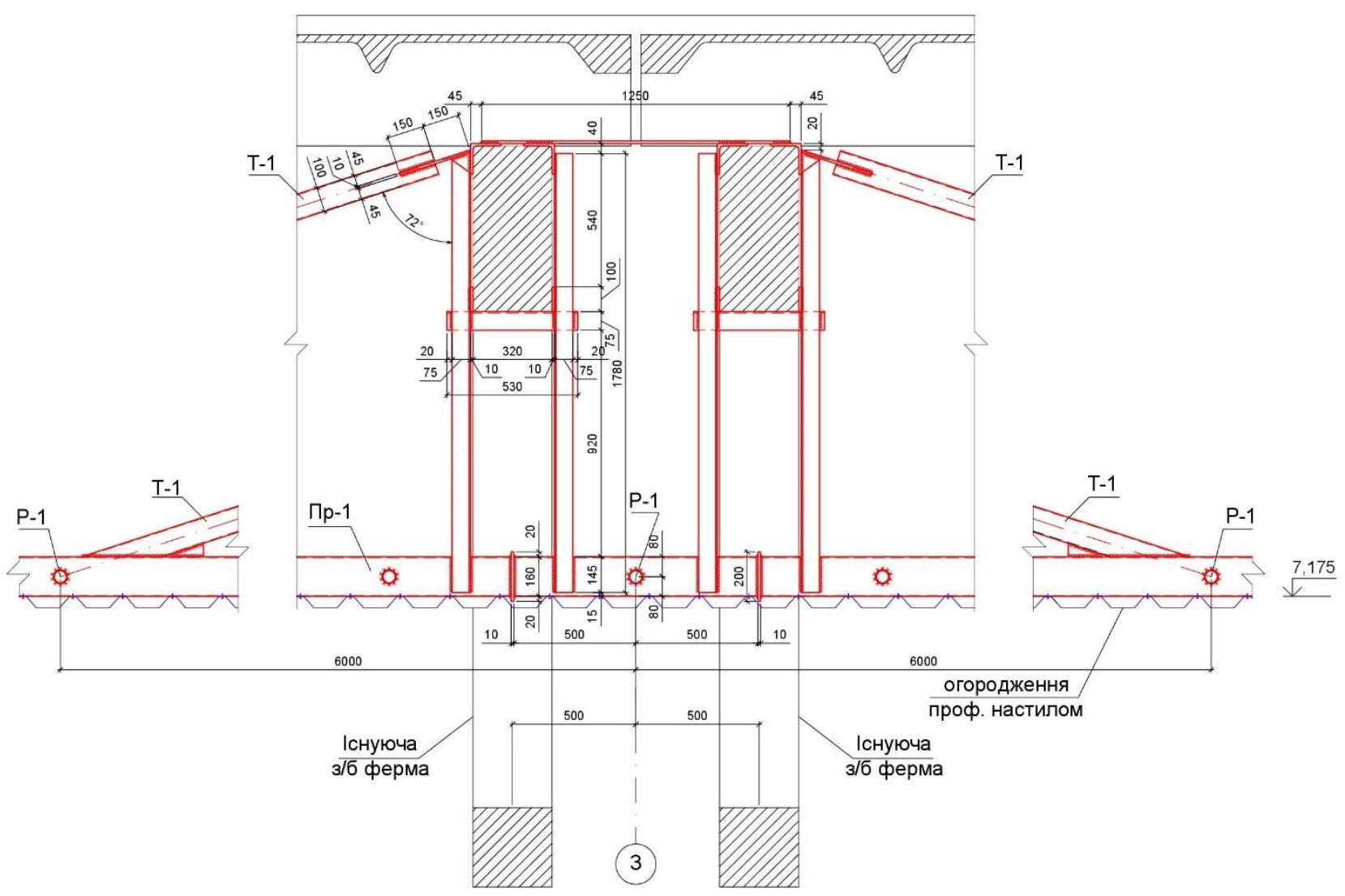

Малюнок 7. Вузол «1» - підвіска прогонів до верхнього поясу ферм

Запропонований варіант конструкції прохідної підвісної стелі задовольнив усі поставлені вимоги та дозволив у короткі строки виконати будівельномонтажні роботи (мал. 8,9 ).
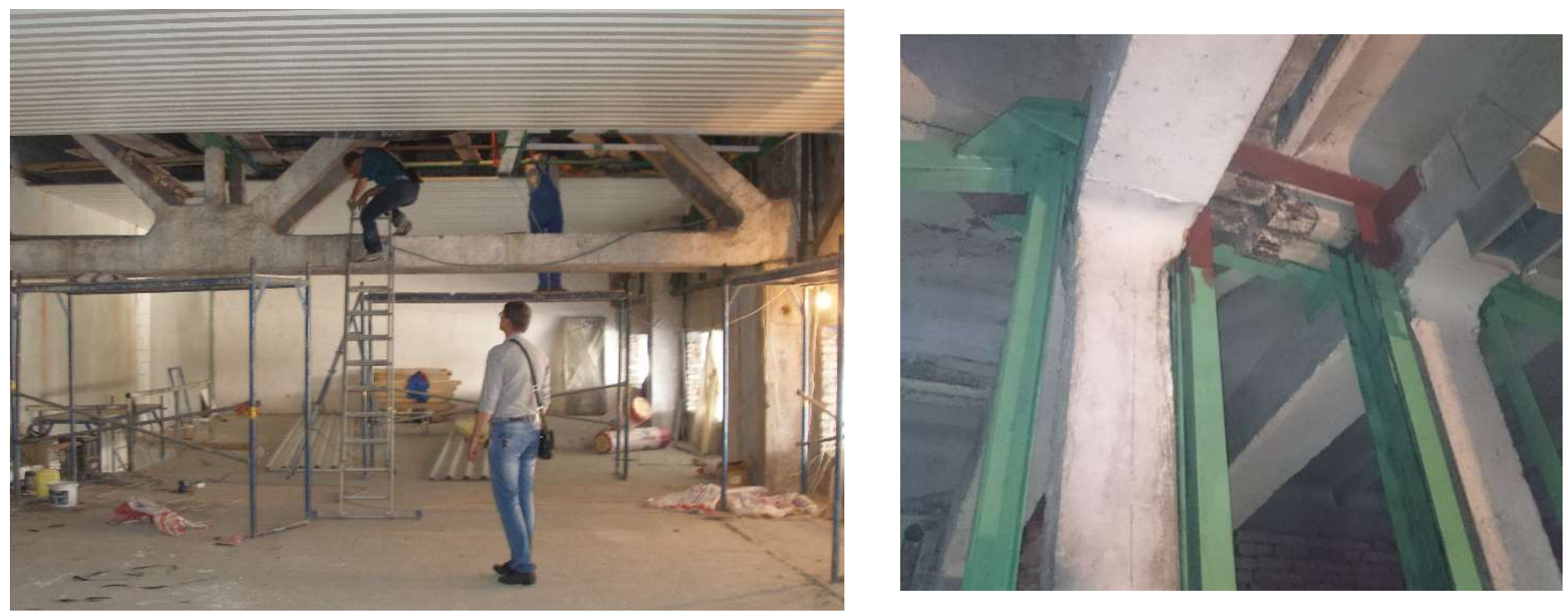

Малюнок 8. В процесі виконання робіт по влаштуванню підвісної стелі 
SCIENTIFIC FOUNDATIONS OF SOLVING ENGINEERING TASKS AND PROBLEMS

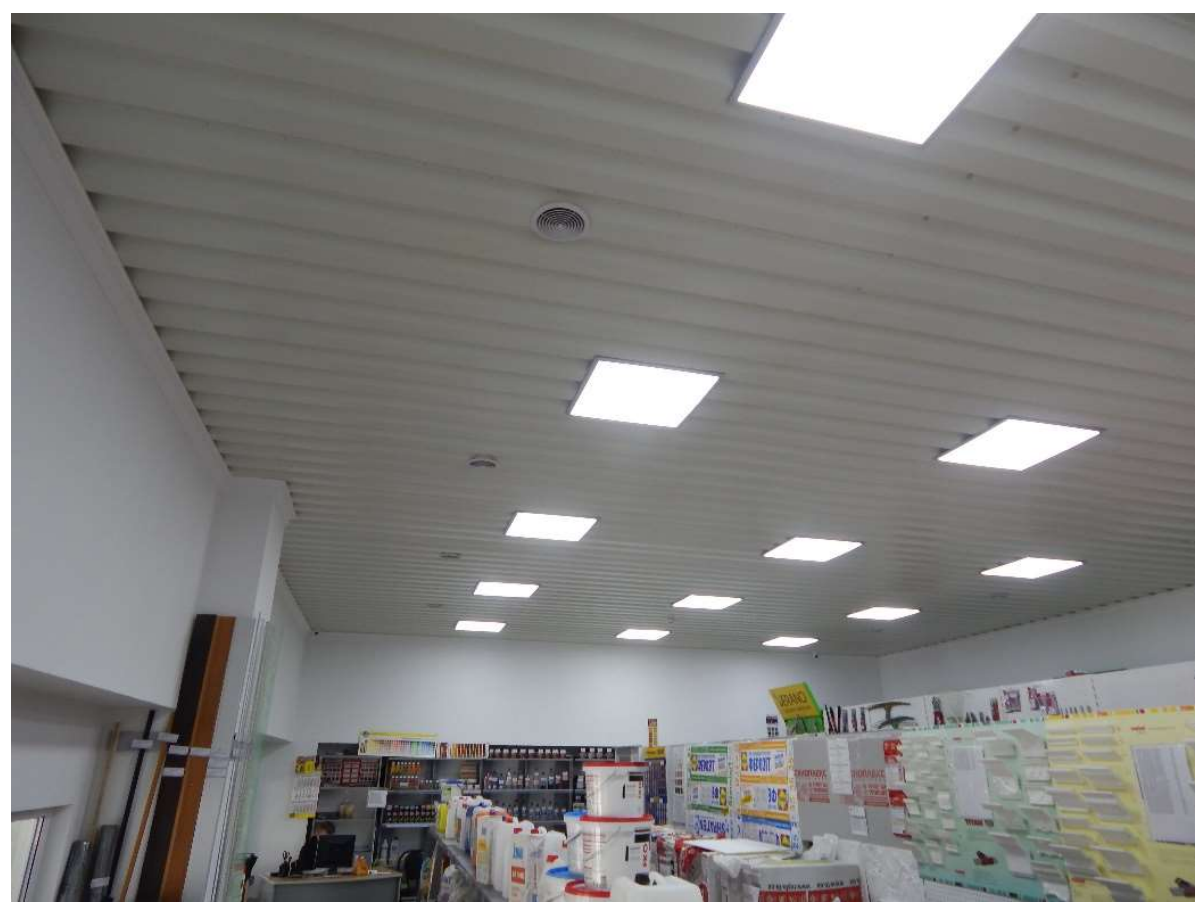

Малюнок 9. Вид виконаної підвісної стелі в процесі експлуатації 